\title{
Acute toxicity of water extract of Tephrosia vogelii Hook to species relevant in aquaculture ponds: rotifers, Cyclops, mosquito larvae and fish
}

\author{
By A. Agbon, C. Ofojekwu and I. Ezenwaka \\ Fisheries and Hydrobiology Research Unit, Department of Zoology, University of Jos, Jos, Nigeria
}

\begin{abstract}
Summary
Rotenone is used to clear ponds of unwanted organisms and trash fish which may predate on fish when the ponds are stocked. Toxicity tests using water extract of the leaves of Tephrosia vogelii Hook, which contains rotenone, were conducted on rotifers (Brachionus species), Cyclops, mosquito larvae (Culex species) and fish (Aphyosemion gardneri nigerianum) in static bioassays. The $48-\mathrm{h} \mathrm{LC}_{50} \mathrm{~s}$ were derived from probit curves using the probit-analysis method, while chisquare was used to test for significant differences between observed mean mortalities and predicted mean mortality values. These showed no significant differences $(P>0.05)$. The variance ratio of the replicates in each treatment also showed no significant difference $(\mathrm{P}>0.05)$. The $48-\mathrm{h} \mathrm{LC}_{50} \mathrm{~S}$ were found to be $2.89,1.04,4.48$ and $0.24 \mathrm{mg} \mathrm{L}^{-1}$ for rotifers, Cyclops, mosquito larvae and fish, respectively. The probit mortalities were positively correlated with the log-concentration, except for the rotifers bioassay, which was negative. The fish, A. gardneri nigerianum, was the most sensitive; the mosquito larvae were the least sensitive.
\end{abstract}

\section{Introduction}

Prior to nursery or production pond stocking, a common practice by aquaculturists is to eliminate all unwanted species and predators. The preparation involves eradication of predatory and trash fish by the application of ichthyotoxins. Until recently, organochlorine chemicals were used (Omoregie et al., 1990).

Tephrosia vogelii Hook is an ichthyotoxic plant grown in tropical countries (Reed et al., 1967; Cox, 1979; Welcomme, 1985; Lambert et al., 1993) and used by artisanal fishermen. Apart from being extremely toxic to fish (Hassal, 1982; Ackerman and Bellwood, 2000), the active ingredient rotenone has been reported to possess insecticidal properties (Beal and Anderson, 1993; Lambert et al., 1993). It inhibits the respiratory chain (Fukami et al., 1970) and acts by blocking the oxidation of $\mathrm{NADH}_{2}$ (O'Brien, 1978), which depletes the cells of ATP needed to maintain mitochondrial energization when electron transport is inhibited (Simbula et al., 1997). Rotenone degrades rapidly (Loeb and Engstrom-Heg, 1970) and bioaccumulation thereof is not a hazard (Gunther and Turrell, 1942; Hassal, 1982). Rotenoids are composed of an isoflavone nucleus with an isoprene moiety attached (Lambert et al., 1993); they are essentially extracted from the root of Derris elliptica (Beal and Anderson, 1993). These compounds also accumulate in the leaves of $T$. vogelii (Lambert et al., 1993) as well as in the floral parts and roots of $T$. fulvinerius and T. pentaphylla (Dagne et al., 1989). A great variety of rotenoids have been reported to accumulate in the leaves of this plant, wherein the total rotenoid content can reach as much as $4 \%$ of the dry matter (Lambert et al., 1993). It is also one of the commercial sources of rotenone listed by Gaskin and Stone (1971). It can also have serious impacts on aquatic ecosystems by affecting organisms other than the target species (Beal and Anderson, 1993).

In the eradication of undesirable species from a periodically reclaimed pond, Orciari (1979) reported that the 48-h $\mathrm{LC}_{50}$ of rotenone in golden shiners was $0.32 \mathrm{mg} \mathrm{L}^{-1}$. Beal and Anderson (1993) reported the eradication of grass carp from a pond at $6 \mu \mathrm{L} \mathrm{L} \mathrm{L}^{-1}$ rotenone concentration. Hegen (1985) reported that there was a total mortality of fish at $5.00 \mathrm{ppm}$ rotenone concentration, while blue crabs and brown shrimps survived at $4.00 \mathrm{ppm}$ and $1.80 \mathrm{ppm}$ concentrations, respectively. Early studies by Brown and Ball (1942) showed that rotenone is toxic to zooplankton at a $1 \mu \mathrm{l} \mathrm{L} \mathrm{L}^{-1}$ concentration, but Hooper (1948) reported rotenone toxicity to be $<1 \mu \mathrm{L}^{-1}$. However, Beal and Anderson (1993) found that rotenone concentrations toxic to zooplankton were almost three times higher than those reported in Brown and Ball (1942).

The use of ichthyotoxic plants is gaining popularity, but there is a dearth of literature on the toxicity of $T$. vogelii to fish. Aphyosemion gardneri nigerianum Clausen 1963 (family: Cyprinodontidae) is a common trash fish inhabiting abandoned/ disused ponds. This study was undertaken primarily to evaluate the toxicity of water extract of $T$. vogelii on A. gardneri nigerianum, mosquito larvae (Culex species), Cyclops species and rotifer (Brachionus species). They form part of the natural food chain of aquatic ecosystems, are the major aquatic organisms found inhabiting disused ponds, and need to be eliminated upon reactivation of such ponds for aquaculture.

\section{Materials and methods}

\section{Test organisms}

The rotifers were obtained from pure culture in the laboratory as described by Lubzens (1987). The Cyclops were obtained from 400-L capacity outdoor metal tanks in which productivity was stimulated by addition of poultry droppings (Wade and Stirling, 1999). Mosquito larvae were obtained by collecting their eggs from an outdoor metal tank and allowing them to hatch in 1-L capacity transparent glassware. They were allowed to grow to second instar stage before bioassay testing. The fish, A. gardneri nigerianum (Family: Cyprinodontidae), were collected from a disused pond and transported to the laboratory in 20 -L plastic bowls. They were acclimated in $19^{\circ} \mathrm{C}$ dechlorinated municipal tap water [dissolved oxygen (DO): 
$8.20 \mathrm{mg} \mathrm{L}^{-1}$; $\mathrm{pH}$ 6.7] for a 2-week period during which they were fed daily to satiation with live mosquito larvae at 08.00 and 18.00 hours prior to exposure in bioassay testing media.

\section{Test solution}

Fresh green leaves of $T$. vogelii were collected from a garden and spread on metal trays for air-drying in the laboratory. After $72 \mathrm{~h}$, a constant weight was reached. The dried leaves were pounded in a mortar and sieved with a Gallenkamp sieve ( $90 \mu$ mesh size). The resulting powder was weighed on a Mettler MH80 balance. The test stock solution was prepared by dissolving $50 \mathrm{~g}$ of the powder in $1000 \mathrm{ml}$ distilled water. This mixture was allowed to stand for $24 \mathrm{~h}$ at room temperature $\left(19^{\circ} \mathrm{C}\right)$, decanted and filtered through a No. 1 Whatman filter paper. The filtrate (stock solution) was frozen and maintained at $-20^{\circ} \mathrm{C}$ until required.

\section{Bioassay}

The bioassay tests to determine the 48-h acute toxicity of the $T$. vogelii extract were conducted in a renewable static system (OECD, 1981). Serial dilutions were made from the stock solution at the following concentrations: 10.0, 5.0, 2.5, 1.25, $0.625,0.312$ and $0.156 \mathrm{mg} \mathrm{L}^{-1}$, except for the mosquito larvae bioassay, which required higher toxicant concentrations at $40.0,20.0,10.0,5.0,2.5,1.25$, and $0.625 \mathrm{mg} \mathrm{L}^{-1}$ for mortality to occur.

The rotifer bioassay was conducted in $25 \mathrm{ml}$ glass specimen bottles. The media were inoculated with $1 \mathrm{ml}$ of rotifers obtained from the pure culture (2400 individuals $\mathrm{ml}^{-1}$ ) and each treatment concentration was triplicated. To determine mortality in each replicate, after thorough stirring, three $1 \mathrm{ml}$ aliquots were collected with the aid of a $1 \mathrm{ml}$ insulin syringe, poured into a $1 \mathrm{ml}$ counting chamber and then mounted on a SWIFT microscope for observation under low power. Enumeration was undergone with a tally counter and the mean mortality per treatment was noted. The variance between mean mortality in each replicate for each treatment concentration was tested for significant difference. The subsample taken for enumeration was returned to the bioassay medium after counting. Mortality was assumed when heartbeat and cilia movement ceased.

The Cyclops bioassay was conducted in $100 \mathrm{ml}$ capacity glass beakers. Each treatment concentration was duplicated and inoculated with 10 Cyclops using the $1 \mathrm{ml}$ syringe. The Cyclops were viewed through a stereoscopic microscope and assumed dead when heartbeat stopped. The variance in mean mortality recorded in each replicate per treatment concentration was tested for significant difference. The mosquito larvae bioassay tests were carried out in $100 \mathrm{ml}$ capacity glass beakers; the same procedure was repeated as for Cyclops. Death was confirmed when larvae heartbeat ceased.

The fish bioassay tests were conducted in 10-L glass aquaria. Ten fish (mean total length $4.5 \pm 1.2 \mathrm{~cm}$; mean weight $2.7 \pm 0.5 \mathrm{~g}$ ) were put into each aquarium. Each treatment concentration was duplicated and death was recorded when the opercula movement and tail beat stopped and the fish no longer responded to mechanical stimulus (touch). Any observed dead fish was removed from the medium. A variance test of the mortality per replicate for each treatment concentration was tested for significant difference.

Water quality parameters (Table 1) of the bioassay media were determined at the beginning and at the end of the
Table 1

Mean values $(n=63)$ of bioassay media water quality parameters during the $48 \mathrm{~h}$ exposure period

\begin{tabular}{lc}
\hline Parameter & Mean value (SE) \\
\hline Dissolved oxygen $\left(\mathrm{DO}, \mathrm{mg} \mathrm{L}^{-1}\right)$ & $8.17(0.05)$ \\
Total alkalinity $\left(\mathrm{mg} \mathrm{L}^{-1}\right)$ & $153.57(0.53)$ \\
Total hardness $\left(\mathrm{mg} \mathrm{L}^{-1}\right)$ & $75.57(0.53)$ \\
Temperature $\left({ }^{\circ} \mathrm{C}\right)$ & 18.0 \\
pH & $6.68(0.02)$ \\
\hline
\end{tabular}

experiments. The DO, total alkalinity, and total hardness were determined by the methods of APHA (1985). The $\mathrm{pH}$ values were determined by using a Phillips $\mathrm{pH}$ meter model PW9418. Water temperatures were taken with a mercury-in-glass thermometer.

The 48-h $\mathrm{LC}_{50}$, regression analyses and correlation coefficient were determined using Microsoft Excel ${ }^{\circledR}$ Office 2000.

\section{Results}

The 48-h $\mathrm{LC}_{50}$ values of the test organisms exposed to the water extract bioassays of $T$. vogelii were determined from linear $(y=m+b x)$ plots of the probit curves for all the test organisms. These are presented in Fig. 1a-d. The probit mortality percentages of the test organisms were plotted against log-concentrations as described by Sprague (1970, 1971).

For the rotifers, the linear equation $y=18.29-3.84 x$ was derived from the regression analysis of probit mortality in the test solution bioassay. Observed and predicted values are shown in Fig. 1a. The 48-h $\mathrm{LC}_{50}$ was calculated to be $2.89 \mathrm{mg} \mathrm{L}^{-1}$, with a correlation coefficient of -0.833 $(\mathrm{P}=0.0199)$. Chi-square test confirmed the goodness-of-fit of the trend as there was no significant difference between the observed values and the predicted values $(\mathrm{P}>0.05)$. There was also no significant difference between the replicates per treatment, as the calculated variance was found to be far less than $F_{0.05}$.

For the Cyclops bioassay, the linear equation $y=0.52+1.48 x$ was derived from the regression analysis of the probit mortality with a $48-\mathrm{h} \mathrm{LC}_{50}$ of $1.06 \mathrm{mg} \mathrm{L}^{-1}$ and a correlation coefficient of $0.984(\mathrm{P}=5.86 \mathrm{E}-05)$. The observed and predicted values are shown in Fig. $1 \mathrm{~b}$. Chi-square test confirmed the goodness-of-fit of the linear plot; there was no significant difference between the observed and the predicted values $(\mathrm{P}>0.05)$. When the variance ratio of mortalities between replicates in each treatment concentration was calculated, there was no significant difference between the replicates, as the calculated variance was found to be far less than $F_{0.05}$.

The mosquito larvae exposed to the $T$. vogelii extract bioassay had a mortality pattern which on regression yielded the linear equation $y=-3.58+2.35 x$. The 48-h $\mathrm{LC}_{50}$ derived from the equation was $4.48 \mathrm{mg} \mathrm{L}^{-1}$. Observed and expected probit mortalities are shown in Fig. 1c, with a correlation coefficient of $0.844(\mathrm{P}=0.0169)$. Chi-square test showed no significant difference between the observed and predicted probit values $(\mathrm{P}>0.05)$. The variance test on the replicates in each treatment concentration revealed that there was no significant difference, as the calculated variance ratio was found to be far less than $F_{0.05}$.

The fish, $A$. gardneri nigerianum, on exposure to the $T$. vogelii extract yielded a mortality pattern as presented in 
Fig. 1. Plots of probit mortality of rotifers (a), Cyclops (b), mosquito larvae (c) and (d) Aphyosemion gardneri nigerianum in Tephrosia vogelii Hook extract
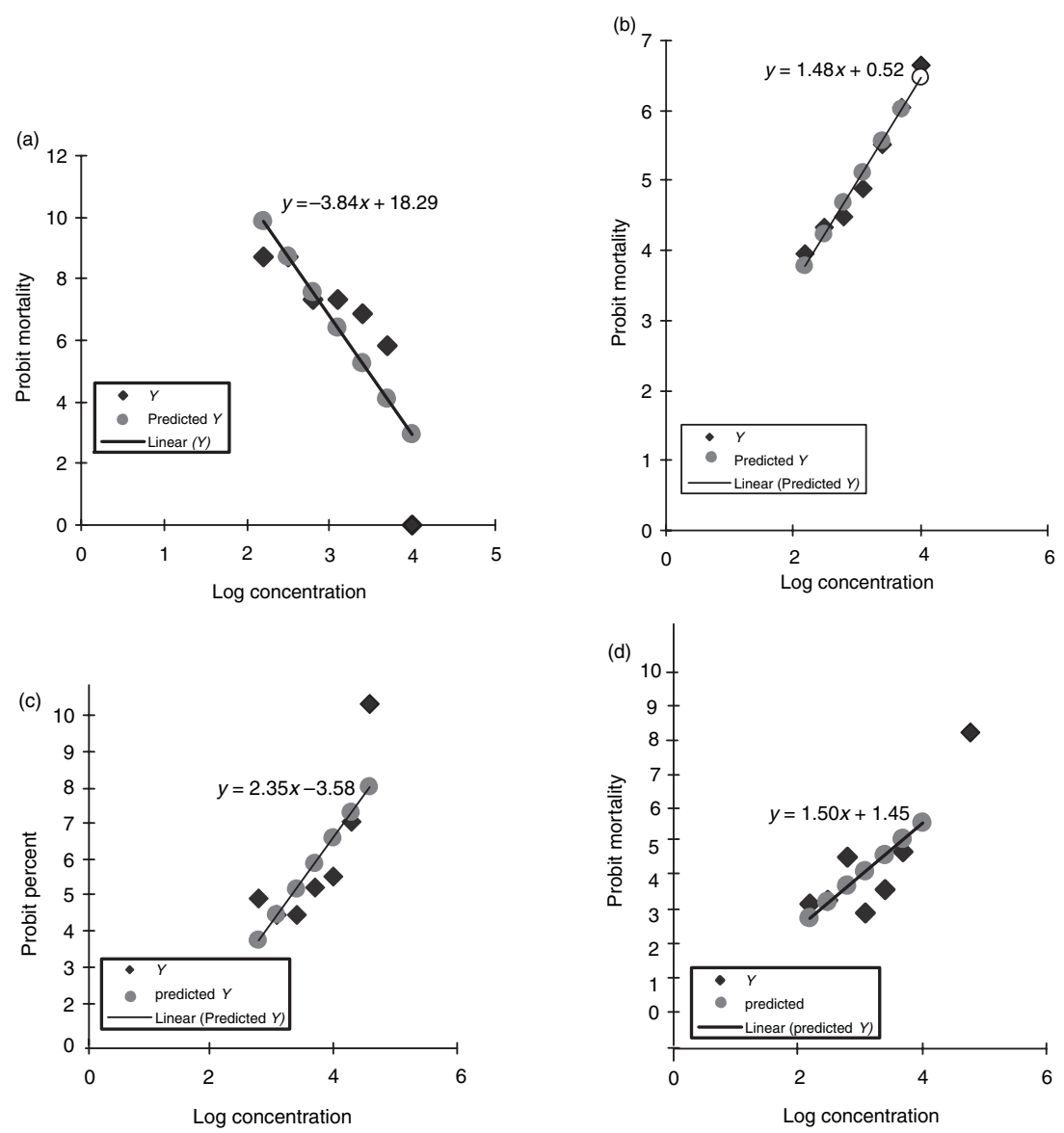

Fig. 1d. Regression analysis gave a linear equation, $y=1.45+1.50 x$. Observed and predicted probit values are shown with a correlation coefficient of $0.724(\mathrm{P}=0.0659)$. The $48-\mathrm{h} \mathrm{LC}_{50}$ was calculated to be $0.232 \mathrm{mg} \mathrm{L}^{-1}$. Chi-square test found no significant difference between the observed and the predicted probit values $(\mathrm{P}>0.05)$. There was also no significant difference between the mortalities recorded in the replicates for each treatment concentration, as the calculated variance ratio was found to be less than $F_{0.05}$.

\section{Discussion}

Ponds not in active production are normally invaded by organisms such as insects, amphibians and reptiles, as well as trash and predatory fish species. Some of these organisms could predate on the cultured fish or compete with them for food and oxygen if they are not eliminated before stocking. Some aquaculturists in Nigeria use agrochemicals for eradication; other aquaculturists use plants with ichthyotoxic properties. Artisanal fishermen use T. vogelii to fish in creeks, pools and isolated channels of principal rivers (Reed et al., 1967; Cox, 1979), while researchers (Hegen, 1985; Ackerman and Bellwood, 2000, 2002) and aquaculturists (Meyer et al., 1976; Orciari, 1979; Beal and Anderson, 1993) use commercial rotenone in fish biodiversity studies and in elimination of unwanted fish species from ponds, respectively.

The $48-\mathrm{h} \mathrm{LC}_{50}$ of the acute toxicity tests reveals that $T$. vogelii extract, with a value of $0.24 \mathrm{mg} \mathrm{L}^{-1}$, is more toxic to fish than any of the other test organisms in this study. This value compares favourably with that reported for golden shiners by Orciari (1979). Beal and Anderson (1993) eradicated grass carp from a pond with a rotenone concentration of $6 \mu \mathrm{L} \mathrm{L}^{-1}$. The 48-h $\mathrm{LC}_{50}$ for Cyclops and rotifers was $1.04 \mathrm{mg} \mathrm{L}^{-1}$ and $2.89 \mathrm{mg} \mathrm{L}^{-1}$, respectively. Beal and Anderson (1993) reported eradication of zooplankton (Copepoda, Cladocera and Rotifera) at a concentration of $3 \mu \mathrm{l} \mathrm{L} \mathrm{L}^{-1}$, which was almost three times higher than that reported by Brown and Ball (1942). Hegen (1985) reported that brown shrimps survived only up to a concentration of $1.8 \mathrm{ppm}$. Mosquito larvae were least sensitive to $T$. vogelii extract, with a 48-h $\mathrm{LC}_{50}$ value of $4.48 \mathrm{mg} \mathrm{L}^{-1}$; this relatively high value might be due to the fact that the larvae (Culex species) breathe atmospheric air (Ukoli, 1984; Segun, 1989), reducing the rate of extract absorption into the organism. Rotenone is a respiratory inhibitor (Hogson et al., 1988), and exposure of rotenone to the respiratory organs is minimal in mosquito larvae when compared with the other test organisms. The observation that rotifers showed a negative correlation in the bioassay, implying that more rotifers survived at higher extract concentrations, was rather an unexpected behaviour; this observation requires further investigation to elucidate the reason(s) responsible for the pattern.

The rotenone in the $T$. vogelii extract in this study is more toxic to aquatic organisms when compared with other authors who studied plants possessing ichthyotoxic properties. Chen et al. (1996) reported the 48-h $\mathrm{LC}_{50}$ of saponin on juvenile Penaeus japonicus to be $20.82 \mathrm{mg} \mathrm{L}^{-1}$. Saha and Kaviraj (1996) reported the $96 \mathrm{~h} \mathrm{LC}_{50}$ of tannic acid obtained from spent bark cinchona to be $55 \mathrm{mg} \mathrm{L}^{-1}$ on Oreochromis mossambicus. Onusiriuka and Ufodike (1994) reported the 96-h LC $_{50}$ values of spent bark extract of Blighia sapida (Akee apple) and Kigelia africana (sausage plant) on African 
catfish (Clarias gariepinus) to be $8.32 \mathrm{mg} \mathrm{L}^{-1}$ and $26.92 \mathrm{mg} \mathrm{L}^{-1}$, respectively.

Use of rotenone by Beal and Anderson (1993) eliminated all zooplankton from the water column in a pond. One to eight months were needed for the zooplankton community to recover to pre-rotenone application levels. Cyclopoid reappeared after 30 days, while the rotifers began to re-occur after 45 days.

The benefits of natural foods for fish culture have been reported by Little and Muir (1987). Wade and Stirling (1999) noted that Rotifera and Cyclopoids are nutritious and beneficial zooplankton to fry, juveniles and adult fish in culture systems. Rotifers and Cyclops form part of the natural foods for aquaculture in Nigeria. The use of Artemia salina by fish farmers in Nigeria is declining because it is expensive. The clearing of ponds before stocking may, therefore, pose a threat to the natural food sources for stocked fry and fingerlings. Beal and Anderson (1993) recommended a delay in restocking until natural communities were re-established. However, the practice by many farmers is usually to stimulate natural productivity of the pond ecosystem by bio-manipulation (Wade and Stirling, 1999) after treatment with ichthyotoxin.

Calow (1992) argued that the gap in relating laboratory tests to natural situations could be bridged by introducing a safety factor of dividing the estimated $\mathrm{LC}_{50}$ by 10 . When this is applied here, the safety level of the water extract of $T$. vogelii on the test organisms becomes $0.289,0.104,0.445$ and $0.024 \mathrm{mg} \mathrm{L}^{-1}$ for rotifers, Cyclops, mosquito larvae and fish, respectively. Given the estimated safety level of $0.289 \mathrm{mg} \mathrm{L}^{-1}$ for rotifers, even when concentrations above the $\mathrm{LC}_{50}$ value for fish $\left(0.24 \mathrm{mg} \mathrm{L}^{-1}\right)$ are applied to nursery or production ponds, the Rotifera population would not be eliminated, thus providing live food for the fry.

In conclusion, this study revealed that the water extract of T. vogelii is very toxic to fish and other aquatic organisms when compared with other icthyotoxins of plant origin. The unregulated use of this plant by artisanal fishermen should be discouraged because of the potential risk posed to natural populations in aquatic ecosystems; concentrations lower than the safety values may exhibit different degrees of chronic effects on aquatic biocenosis and, hence, recruitment into the fisheries of natural water bodies where they are applied.

\section{References}

Ackerman, J. L.; Bellwood, D. R., 2000: Reef fish assemblages: a re-evaluation using enclosed rotenone stations. Mar. Ecol. Prog. Ser. 206, 227-237.

Ackerman, J. L.; Bellwood, D. R., 2002: Comparative efficiency of clove oil and rotenone for sampling tropical reef fish assemblages. J. Fish Biol. 60, 893-901.

American Public Health Association (APHA), 1985: Standard methods for the examination of water and wastewater, 16th edn. American Public Health Association, Washington, DC, 1268 pp.

Beal, D. L.; Anderson, R. V., 1993: Response of Zooplankton to rotenone in small pond. Bull. Environ. Contam. Toxicol. 51, 551556.

Brown, D. C.; Ball, R. C., 1942: An experiment in the use of derris root (rotenone) on the fish and fish food organisms of Third Sister Lake. Trans. Am. Fish. Soc. 72, 267-284.

Calow, P., 1992: The three Rs of ecotoxicology. Funct. Ecol. 6, 617619.

Chen, J. C.; Chen, K. W.; Chen, J. M., 1996: Effects of saponin on survival, growth, molting and feeding of Penaeus japonicus juveniles. Aquaculture 144, 165-175.

Cox, P. A., 1979: Use of indigenous plants as fish poisons in Samoa. Econ. Bot. 33, 397-399.
Dagne, E.; Yenesew, A.; Waterman, P. G., 1989: Flavonoids and isoflavonoids from Tephrosia fulvinerius, Tephrosia pentaphylla. Phytochemistry (Oxford) 28, 3207-3210.

Fukami, J.; Mitsui, T.; Fukunuga, K.; Shishido, T., 1970: The selective toxicity of rotenone between mammal, fish and insect. In: Biochemical toxicology of insecticides. R. D. O'Brien and I. Yamamoto (Eds). Academic Press, London, pp. 159-178.

Gaskin, M. H.; Stone, E. G., 1971: The levels of Tephrosia vogelii as a potential commercial source of rotenoids for insecticides and piscicides. Agron. J. 63, 899-900.

Gunther, F. A.; Turrell, F. M., 1942: A preliminary report of a critical examination of the roots of Derris elliptica. J. Econ. Entomol. 35, 941.

Hassal, K. A. (Ed.) 1982: The chemistry of pesticides. Macmillan Press, London, 372 pp.

Hegen, E. H., 1985: Use of rotenone and potassium permanganate in esturine sampling. N. Am. J. Fish Manage. 5(3B), 417-506.

Hogson, E.; Mailman, R.; Chamber, J. (Eds) 1988: Dictionary of toxicology. MacMillan Press, London, 328 pp.

Hooper, F., 1948: The effect of derris root on plankton and bottom fauna organisms of a small Minnesota lake. Proc. Minn. Acad. Sci. 16, 29-32.

Lambert, N.; Trouslot, M. F.; Campa, C. N.; Chrestin, H., 1993: Production of rotenoids by heterotrophic and photomixotrophic cell cultures of Tephrosia vogelii. Phytochemistry 34, 1515-1520.

Little, D.; Muir, J., 1987: A guide to integrated warm water aquaculture. Institute of Aquaculture, University of Stirling Publication, Stirling, Scotland. 238 pp.

Loeb, H.; Engstrom-Heg, R., 1970: Time dependent changes in toxicity of rotenone dispersions to trout. Toxicol. Appl. Pharmacol. 17, 605-614.

Lubzens, E., 1987: Raising rotifers for use in aquaculture. Hydrobiologia 147, 245-255.

Meyer, F. P.; Schick, R. A.; Cumming, K. B., 1976: Registration status for fishery chemicals. Prog. Cult. 38, 3-7.

O'Brien, R. D., 1978: The biochemistry of toxic action of insecticide. In: Biochemistry of insects. M. Rockstein (Ed.). Academic Press, New York, pp. 515-539.

OECD, 1981: Guidelines for testing chemicals, no. 202. ISBN 92-641221-4. Organisation of Economic Co-operation and Development, Paris, 15 pp.

Omoregie, E.; Ufodike, E. B. C.; Keke, I. R., 1990: Tissue chemistry of Oreochromis niloticus exposed to sublethal concentrations of Gammalin 20® and Actellic 25EC®. J. Aquat. Sci. 5, 33-36.

Onusiriuka, B. C.; Ufodike, E. B. C., 1994: Acute toxicity of Akee apple, Blighia sapida and sausage plant, Kigelia africana of African catfish, Clarias gariepinus (Teugals). J. Aquat. Sci. 9, $35-41$.

Orciari, D. R., 1979: Rotenone resistance of golden shiners from a periodically reclaimed pond. Trans. Am. Fish. Soc. 108, 641-645.

Reed, W.; Burchard, J.; Hopson, A. J.; Jenness, J.; Yaro, I. (Eds) 1967: Fish and fisheries of northern Nigeria. Gaskiya Corporation, Zaria, Nigeria, 226 pp.

Saha, N. C.; Kaviraj, A., 1996: Acute and chronic toxicity of tannic acid and spent bark of cinchona on tilapia, Oreochromis mossambicus. Aquaculture 145, 119-127.

Segun, A. O. (Ed.) 1989: Tropical zoology. University Press, Ibadan, Nigeria, $245 \mathrm{pp}$.

Simbula, G.; Glascott, P. A.; Akita, S.; Hoek, J. B.; Faber, J. L., 1997 : Two mechanisms by which ATP depletion potentiate induction of the mitochondrial permeability transition. Am. J. Physiol. 273, $479-488$.

Sprague, J. B., 1970: Measurement of pollutant toxicity to fish: II. Utilizing and applying bioassay results. Water Res. 4, 3-32.

Sprague, J. B., 1971: Measurement of pollutant toxicity to fish: III. Sublethal effects and safe concentrations. Water Res. 5, 245-266.

Ukoli, F. M. A. (Ed.) 1984: Introduction to parasitology in tropical Africa. John Wiley \& Sons, London, 464 pp.

Wade, J. W.; Stirling, H. P., 1999: Fertilisation of ponds: II. Effects on plankton communities. J. Aquat. Sci. 14, 13-18.

Welcomme, R. L. (Ed.) 1985: River fisheries. FAO technical paper 262. FAO, Rome, 330 pp.

Author's address: Andrew Agbon, Department of Aquaculture and Fisheries Management, University of Agriculture, P.M.B. 2240, Abeokuta, Nigeria. E-mail: oseremehis@yahoo.co.uk 